\title{
Impacts of supplementation aquaculture on the genetic diversity of wild Ruditapes decussatus from northern Spain
}

\author{
Bereket Tesfamariam Habtemariam¹, Andrés Arias², Eva García-Vázquez¹, \\ Yaisel Juan Borrell ${ }^{1, *}$ \\ ${ }^{1}$ Department of Functional Biology, University of Oviedo, C/ Julián Clavería s/n, 33006 Oviedo, Spain \\ ${ }^{2}$ Department of Biology of Organisms and Systems (BOS), University of Oviedo, C/ Catedrático Rodrigo Uría s/n, \\ 33071 Oviedo, Spain
}

\begin{abstract}
The European carpet shell Ruditapes decussatus is among the most important shellfish species cultured in estuaries and bays of the northern Iberian Peninsula. Increased demand and overfishing of native $R$. decussatus, as well as irregular yields due in part to pollution and urban sprawl, have led to overexploitation of the species and to the import of the non-indigenous $R$. philippinarum in the early 1980s. In recent years, supplementation aquaculture of $R$. decussatus (supportive breeding) has been implemented as a management tool to recover the exhausted native carpet shell populations in Asturias, northern Spain. In this study, taxonomic analysis and a suite of genetic markers (ITS2, 5SrDNA, and mtCOI) were employed to assess the genetic composition of $R$. decussatus in 2 estuaries of the region, Ría del Eo and Ría de Villaviciosa. Our results revealed species misidentification and evidenced genetic introgression from the non-indigenous $R$. philippinarum into wild $R$. decussatus samples $(4.2 \%)$, as well as in the aquaculture seed used for population supplementation $(2.0 \%)$. Furthermore, we found significant genetic differentiation $\left(F_{\mathrm{ST}}=0.03750, \mathrm{p}<0.0001\right)$ between wild populations and aquaculture seed, while the adults of both estuaries were genetically homogeneous $(p>0.05)$. Several actions are strongly recommended to prevent inadvertent introduction of non-indigenous genomes and other genetic erosive processes on native species in the region: (1) banning releases of the alien species $R$. philippinarum, (2) developing diagnostic tests for detection of hybrids in captive breeding programs, and (3) assessing the conservation status of wild $R$. decussatus populations.
\end{abstract}

KEY WORDS: Carpet shells · Shellfish harvesting • Veneridae supplementation · Hybrid swarm · Genetic diversity $\cdot$ Hybridization

\section{INTRODUCTION}

Aquaculture-based enhancement projects, or supplementation aquaculture, are practiced worldwide to overcome species overexploitation and habitat loss or degradation (Masuda \& Tsukamoto 1998, Utter \& Epifanio 2002). In this strategy, hatchery-raised juveniles (fish and shellfish) are released into wild populations to compensate for a shortage in juvenile recruitment and eventually contribute to fishery har-

*Corresponding author: borrellyaisel@uniovi.es vest (Bert et al. 2007). It is a management tool used to recover depleted populations. For successful enhancement programs, supplementation aquaculture should be incorporated within the general framework of fisheries and ecosystem management plans, using sound enhancement strategies such as adequate genetic resources management to avoid harmful genetic alterations on wild populations (Blankenship \& Leber 1995, Molony et al. 2003, Lorenzen et al. 2010). There are growing concerns about the genetic

(C) The authors 2015. Open Access under Creative Commons by Attribution Licence. Use, distribution and reproduction are unrestricted. Authors and original publication must be credited. 
consequences of enhancement practices on wild populations (Gaffney 2006, Araki et al. 2009). They include (1) identifying the correct genetic makeup that is representative of the recipient population to avoid disruption of local genetic adaptation as well as (2) maintaining the maximum genetic variability possible and reducing inbreeding of hatchery stocks used for restoration purposes. Enhancement programs are usually performed using a small number of breeders that produce genetically less diverse hatchery progeny (Utter 1998, Gaffney 2006, Roodt-Wilding 2007). When hatchery offspring with low genetic diversity are introduced into wild populations, they tend to lower the overall genetic variability and decrease the fitness of the resulting populations through inbreeding (Gaffney 2006, Roodt-Wilding 2007, Araki \& Schmid 2010).

The European (or grooved) carpet shell Ruditapes decussatus (Linnaeus, 1758) is among the most important cultured species in estuarine and coastal waters of Spain. It is a native species with a natural distribution in the eastern Atlantic from the British Isles to Senegal and into the Mediterranean Sea (Gofas et al. 2011, Juanes et al. 2012, Borrell et al. 2014). This species is quite variable in shape and color as well as in shell sculpture, ranging from practically smooth to moderately reticulate (Poppe \& Goto 2000). Increased demand and overfishing of the native $R$. decussatus, as well as irregular yields due to pollution and urban sprawl have led to overexploitation of this species and subsequently, to imports of the Manila clam R. philippinarum (Adams \& Reeve, 1850) into Spanish waters in 1982 (Cigarria et al. 1997, Bidegain \& Juanes 2013). R. philippinarum, originally from Indo-Pacific coastal waters, is currently spreading worldwide, covering the Pacific coast of North America, Atlantic coasts of Europe, and the Mediterranean Sea; it is also very common in the Adriatic and Aegean Seas (Jensen et al. 2004). Following the introduction of $R$. philippinarum to Europe in 1972 via French hatchery production, it has become the major contributor to clam landings in Europe (mainly in France, Italy, and Ireland) because the Manila clam shell is more resistant to disease and has a faster growth rate than the indigenous species R. decussatus (Laruelle et al. 1994, Moreira et al. 2012, Chiesa et al. 2014). This non-indigenous species (NIS) is widely distributed across the coasts of the Cantabrian Sea (Arias \& Anadón 2012, Bidegain \& Juanes 2013) and has been reported as one of the main biological invaders throughout the world as a consequence of aquaculture activities (Ruiz et al. 1997, Olenin et al. 2010).
One of the ecological impacts of NIS aquaculture is hybridization with native species (Clavero \& GarciaBerthou 2005, Molnar et al. 2008, Olenin et al. 2010). Huvet et al. (2004) reported hybridization between introduced Crassostrea gigas (Thunberg, 1793) and the Portuguese oyster C. angulata (Lamarck, 1819), with dramatic consequences for the latter species. Another example occurs in the genus Mytilus in North America. Aquaculture practices of the NIS M. galloprovincialis (Lamarck, 1819) in northeast Pacific coasts cause hybridization between this species and the native M. trossulus Gould, 1850 (e.g. Rawson et al. 1999, Crego-Prieto et al. 2015), and although hybridization between these 2 species is still limited, the future ecological consequences are still unknown. For carpet shells, Hurtado et al. (2011) demonstrated that reproductive barriers are incomplete between $R$. decussatus and $R$. philippinarum: hybrids occur and genetic introgression is theoretically possible between the 2 species. The extent of such interspecific introgression in wild ecosystems has been assessed only in 1 estuary in northwestern Spain, the Ría de Vigo (Hurtado et al. 2011), where $4 \%$ of sampled $R$. decussatus contained genes of the NIS $R$. philippinarum.

A stock-enhancement program of the indigenous species $R$. decussatus was initiated by the regional government of Asturias. Wild breeders are selected from their natural habitats and are induced to spawn under a controlled environment (García-Pérez et al. 2007). A total of 2570000 seeds were released into the harvest areas of Ría de Villaviciosa and Ría del Eo estuaries between 2009 and 2013 (López et al. 2009, $2010,2011,2013)$. The broodstock used in the hatchery facility is collected from the Ría del Eo estuary. The number of breeders employed is relatively limited, and in 2013, only 13 individuals contributed effectively to offspring (Centro de Experimentación Pesquera, CEP, pers. comm.), although the recommended number is at least 50 for short-term fitness and 500 for long-term survival (Tave 1999, Allendorf \& Luikart 2007). This program has been recently assessed employing microsatellite DNA loci (Borrell et al. 2014). It has been reported that the seeds employed in the enhancement program were genetically different compared to their wild counterparts, and that the wild populations located in the central Cantabrian coast did not differ significantly in their microsatellite allele frequencies. In that study, the possible presence of the NIS $R$. philippinarum was not investigated. If there is introgression in the source populations of enhancement stocks, it is possible that NIS genes are expanding inadvertently via anthropogenic supplementation of wild populations. 
In this study, we investigated the occurrence and extent of introgression of NIS R. philippinarum genes into the source population of hatchery enhancement stocks, the hatchery stock, and the receptor populations of indigenous $R$. decussatus in the central Cantabrian coast (Asturias). For this purpose, we employed taxonomical assessments, 2 nuclear speciesspecific markers (Hurtado et al. 2011), and the mitochondrial cytochrome oxidase subunit I (mtCOI), which is the most employed DNA region for animal species identifications (DNA barcoding; Hebert et al. 2003). Polymorphism at this region was additionally investigated to evaluate the genetic diversity of the locally exploited and supplemented wild $R$. decussatus populations (Ría de Villaviciosa and Ría del Eo estuaries).

\section{MATERIALS AND METHODS}

\section{Sampling}

The study areas of this project were 2 estuaries where clams are cultivated, Ría de Villaviciosa $\left(43^{\circ}\right.$ $\left.53^{\prime} \mathrm{N}, 5^{\circ} 38^{\prime} \mathrm{W}\right)$ and Ría del Eo ( $\left.43^{\circ} 53^{\prime} \mathrm{N}, 7^{\circ} 03^{\prime} \mathrm{W}\right)$. These estuaries are located in the southern Bay of Biscay, northern Iberian Peninsula (Spain; Fig. 1). They are approximately $134 \mathrm{~km}$ apart and separated by the Peñas Cape, which represents a temperature boundary within the Cantabrian coast; it is colder to the west (Ría del Eo) than to the east (Ría de Villaviciosa) due to western upwelling (Dickson \& Hughes 1981, Rios et al. 1987, Muñoz-Colmenero et al. 2012). These estuarine areas play an important role in shellfish production in the Cantabrian Sea.

A total sample of 205 clams was used in this study. Most individuals were adults $(\mathrm{n}=154)$, and the remaining 51 were seeds. These seed clams $(5 \mathrm{~mm}$ in size) were reared by the seed hatchery facility at Castropol (Ría del Eo) to be used in clam population enhancement. They were provided by resource managers of the regional government and were labeled as Ruditapes decussatus. Adult samples were randomly collected and identified by authorized fishermen from the 2 study sites in the wild.

\section{Species identification}

Morphology-based species identification

Since $R$. decussatus and $R$. philippinarum are members of the same genus, they share a great number of

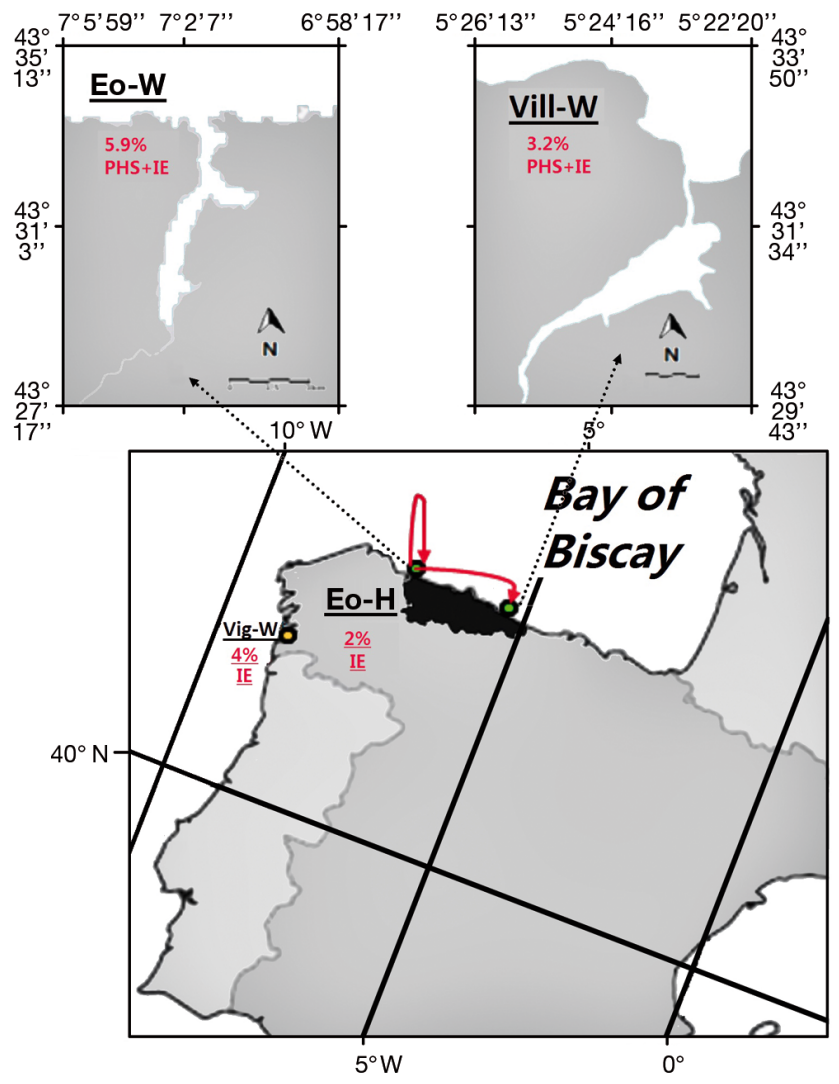

Fig. 1. Location of Asturias in the Bay of Biscay, with details of the 2 study sites: Ría del Eo (Eo) and Ría de Villaviciosa (Vill). Percentages of possible species misidentifications and introgression events (IE) detected in populations of supplemented Ruditapes decussatus from Asturias, northern Spain, after morphology and genetic assessments, are indicated together with previous findings in Ría de Vigo (Vig), Galicia, by Hurtado et al. (2011). Supplementation strategies and thus probable spreading of IE into wild populations are indicated by red arrows. RP: $R$. philippinarum; W: wild; $\mathrm{H}$ : hatchery; PHS: possible hybrid specimen

morphological and anatomical characters. This along with the relatively high polymorphism registered in both species may hinder their correct identification. However, the 2 species can be clearly differentiated on the basis of some diagnostic characters of the shell and siphon morphology (Tebble 1966, Quéro \& Vayne 1998, Poppe \& Goto 2000, Gofás et al. 2011; Fig. 2). $R$. decussatus displays the following main diagnostic features: (1) inside of shell whitish or light yellow without purple spots on muscles and pallial sinus impressions, and ventral margin of valves and pallial sinus pointing to the top of shell (Fig. 2A); (2) reticulated shell sculpture, especially marked at posterior and anterior ends of shell, with radial sculpture as distinct as the concentric one, sometimes absent on central area of valves (Fig. 2B); (3) quadrangular 


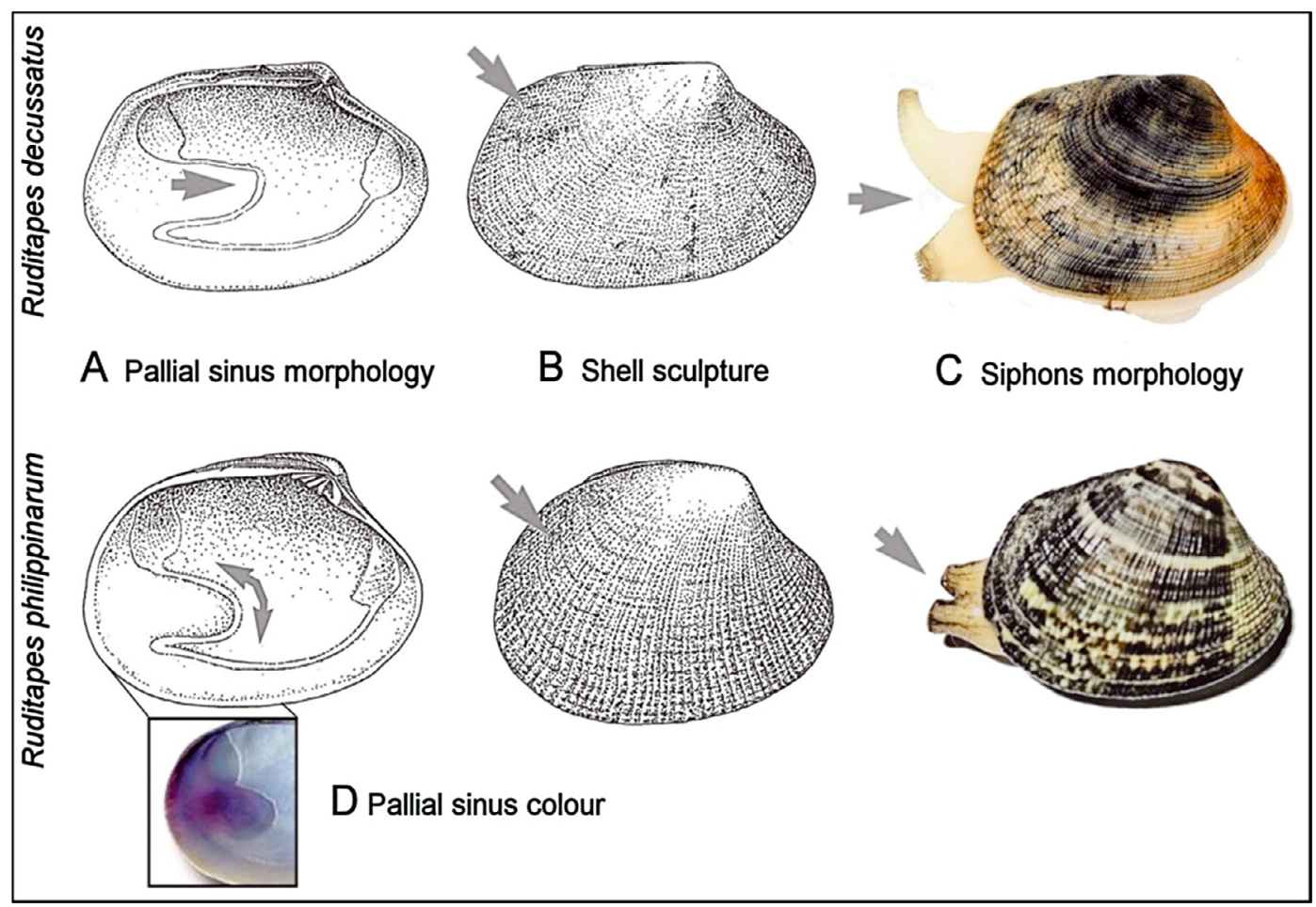

Fig. 2. Simplified identification scheme of Ruditapes decussatus and $R$. philippinarum showing the main morphological differences between the 2 species. A and B modified from Quéro \& Vayne (1998)

shaped shell in outline (Fig. 2B,C), without a large well-defined lunule; (4) separate siphons for most of its length (Fig. 2C). On the other hand, R. philippinarum is mainly characterized by (1) inside of shell commonly with purple spots on muscles and pallial sinus impressions and ventral margin of valves (Fig. 2D), and pallial sinus usually pointed to the ventral margin of shell (Fig. 2A); (2) very pronounced reticulated shell sculpture throughout the whole valve surface, with radial sculpture more distinct than concentric one (Fig. 2B); (3) ovoid shell in outline (Fig. 2B,C) with a large heart-shaped lunule; (4) almost fused siphons for most of its length, only separated at the tips (Fig. 2C). These 4 diagnostic characters were analyzed by taxonomists for all available adult individuals $(\mathrm{n}=154)$. For those cases in which diagnostic characters from both species were found in the same individual (co-occurrence), the classification of 'possible hybrid specimen' was adopted.

\section{Genetic-based species identification}

DNA extraction was performed using the E.Z.N.A.® Mollusc DNA Kit, according to the manufacturer's manual in the 154 adults and 51 seeds collected.
Ruditapes sp. have doubly uniparental inheritance (DUI) of mitochondrial DNA (mtDNA) and 2 different sex-related M- and F-type mtDNAs (Plazzi \& Passamonti 2010 and references therein). These authors, and also Kitada et al. (2013), recommended that DNA should be obtained from the foot or the adductor muscle, as DUI species carry very little M-type mtDNA in those tissues. We therefore used adductor muscle tissue for DNA extractions in adult individuals. DNA extractions for seeds of very small sizes were done using complete individuals, including shells, for digestions. The extracted genomic DNA was checked for quality/quantity by running $3 \mu \mathrm{l}$ of the solution with $2 \mu \mathrm{l}$ loading dye on $2 \%$ agarose/1x TBE gel stained with ethidium bromide $\left(0.5 \mu \mathrm{g} \mathrm{ml}^{-1}\right)$ and stored at $-20^{\circ} \mathrm{C}$.

Three separate PCR amplifications were performed for all individuals, to amplify ITS2, 5SrDNA, and mtCOI genes. Two genes (ITS2 and 5SrDNA) were investigated using size-based analysis of PCR products, and 1 gene (mtCOI) was actually sequenced. Each amplification contained a solution of different concentrations of PCR buffer, $\mathrm{MgCl}_{2}$, dNTPs, primer combinations, Taq, water, and genomic DNA following Hurtado et al. (2011) for nuclear markers and Geller et al. (2013) for the mtCOI gene. In the ampli- 
fication process, a combination of primers ITS3 and ITS4, 5SD, and 5SR were used for ITS2 and 5SrDNA genes, respectively (Hurtado et al. 2011), and the mtCOI gene was amplified from the complete DNA extractions using jgHCO2198 and jgLCO1490 primers designed by Geller et al. (2013). PCR amplification started with an initial denaturation step of $\left(95^{\circ} \mathrm{C}\right.$ for $5 \mathrm{~min}$ ), followed by 35 cycles of $95^{\circ} \mathrm{C}$ for $30 \mathrm{~s}, 48^{\circ} \mathrm{C}$ for $30 \mathrm{~s}$ for ITS2 and 5SrDNA and $50^{\circ} \mathrm{C}$ for $30 \mathrm{~s}$ for $\mathrm{mtCOI}, 72^{\circ} \mathrm{C}$ for $1 \mathrm{~min}$, followed by a final extension of $72^{\circ} \mathrm{C}$ for $5 \mathrm{~min}$ using the Applied Biosystems GeneAmp PCR system 2700 machine. Agarose gel electrophoresis (2\% agarose/1× TBE gel) stained with ethidium bromide was employed to examine the PCR products. The nuclear genes (ITS2 and 5SrDNA), were loaded along with Thermo Scientific GeneRuler DNA Ladder Mix and allowed to run for 60 to $80 \mathrm{~min}$ at 100 V. Fragments were visualized under UV light and photographed using an E-Gel® imaging system. MtCOI PCR products were checked by running gel electrophoresis for $20 \mathrm{~min}$ at $100 \mathrm{~V}$, purified with the protocol of Illustra Exostar 1-Step, and sequenced by Macrogen Inc., The Netherlands.

For mtCOI, the raw chromatograms were manually assembled and visually checked for potential mistakes using the computer software BioEdit 5.0.6 (Hall 1999). Sequences were then aligned, with reference samples obtained from GenBank (GenBank accession number DQ184830 for $R$. decussatus and AB244400 for $R$. philippinarum), using the ClustalW algorithm and were trimmed to attain the same number of base pairs and submitted to GenBank.

Species identification was carried out by examining the 3 genetic markers described above: ITS2, 5SrDNA, and sequences of the mtCOI. The NCBI BLAST algorithm was used to identify the species represented by mtCOI sequences. For species identification, the top hit showing more than $98 \%$ identity was selected. For the nuclear genes, clam species were identified by directly visualizing the amplified PCR fragment from agarose gels. PCR fragment lengths of $482 \mathrm{bp}$ (and $593 \mathrm{bp}$ length of ITS2 and 5SrDNA, respectively) are specific for $R$. decussatus, and in the case of $R$. philippinarum, the specific amplification fragments are $565 \mathrm{bp}$ for ITS2 and $526 \mathrm{bp}$ for 5SrDNA (Hurtado et al. 2011). Individuals with 2 amplified products (482 bp / $565 \mathrm{bp}$ and/or $526 \mathrm{bp} / 593 \mathrm{bp}$ for ITS2 and 5SrDNA, respectively) were classified as hybrids between the 2 species. First-generation hybrids (F1) possess half of their nuclear genes from the maternal species and the other half from the paternal species, and thus 2 fragments of different length for both markers can be observed using gel electrophoresis. However, when F1 hybrids reproduce either with one of its parents or with another F1 hybrid, the resulting offspring may show hybrid pattern for both, one, or none of the loci (Allendorf et al. 2001).

\section{Genetic diversity analysis}

Genetic diversity analysis such as gene diversity ( $h$, the probability of 2 randomly chosen haplotypes being different), and nucleotide diversity $(\pi$, the probability that 2 randomly chosen homologous nucleotides are different), were calculated using DnaSP 5.1 (Librado \& Rozas 2009). A neutrality test was employed to assess the demographic history of the populations. Neutrality statistics, i.e. Tajima's $D$ (Tajima 1989) and Fu's $F_{\mathrm{s}}$ (Fu 1997), were calculated in Arlequin 3.1 (Excoffier et al. 2005). The $D$ and $F_{\mathrm{s}}$ statistic are very sensitive to population demographic expansions. Large negative $D$ and $F_{\mathrm{s}}$ values are characteristic of population expansion, selection, and bottlenecks. Genetic structure in $R$. decussatus was assessed using $F$ statistics and analysis of molecular variance (AMOVA); the significance of the variance components associated with various hierarchical levels of genetic structure within and among populations was estimated using Arlequin 3.1 with 1023 permutations of the data matrix. A median-joining network was constructed using NETWORK 4.5.1.6 (Bandelt et al. 1999) to visualize the spatial relationship of haplotypes. Additional haplotypes from Ruditapes sp. with different geographic origins from Gharbi et al. (2010) (KC 149953, KC149954, KC149956-KC149959), Mao et al. (2011) (AB244374, AB244375, AB244379, AB244380, AB244392, AB244393), Cordero et al. (2014) (JX 051518, JX051520, JX051522-JX051538, JX051541JX051546), and BOLD systems (GBMBV1220_13, GBMBV1225_13， GBMBV694_13-GBMBV697_13, GBMBV997_13, GBMIN1961_12) were used to locate Asturian samples in the worldwide species distribution. Six other $R$. philippinarum haplotypes from Ría de Villaviciosa and Ría del Eo (GenBank accession numbers KJ560352-KJ560357) were also used.

\section{RESULTS}

\section{Species identification}

Details about percentages of possible hybrid specimens and introgression events by population found in this study are presented in Fig. 1 and Table 1. Based on the features of the shell and siphon mor- 
Table 1. Cases of possible species misidentifications (SM) by fishermen detected in individuals from wild (W) and cultured hatchery $(\mathrm{H})$ populations of the supplemented Ruditapes decussatus (RD) from Ría de Villaviciosa (Vill) and Ría del Eo estuaries in Asturias, northern Spain, after taxonomic and genetic assessments (Vill-W: $\mathrm{n}=103$; Eo-W: $\mathrm{n}=51$; Eo-H: $\mathrm{n}=51$ ). (A) SM per source and population type, (B) summary. Bold: different from fishermen's species identification; RP: Ruditapes philippinarum $_{;}$PHS: possible hybrid specimen; Hyb: hybrid; IE: introgression event

\begin{tabular}{|c|c|c|c|c|c|c|}
\hline \multicolumn{2}{|l|}{ A) } & \multicolumn{5}{|c|}{ - Species identification criteria } \\
\hline & & \multicolumn{2}{|c|}{$\begin{array}{c}\text { Species ide } \\
\text { Morphology }\end{array}$} & \multicolumn{3}{|c|}{ Genetics } \\
\hline Case & Source & Fishermen & Taxonomists & mtCOI & ITS2 & 5SrDNA \\
\hline 1 & Vill-W & $\mathrm{RD}$ & PHS & $\mathrm{RD}$ & $\mathrm{RD}$ & $\mathrm{RD}$ \\
\hline 2 & Vill-W & $\mathrm{RD}$ & PHS & $\mathrm{RD}$ & $\mathrm{RD}$ & $\mathrm{RD}$ \\
\hline 3 & Vill-W & RD & $\mathrm{RD}$ & $\mathrm{RD}$ & Hyb (IE) & $\mathrm{RD}$ \\
\hline 4 & Eo-W & $\mathrm{RD}$ & PHS & $\mathbf{R P}$ & $\mathbf{R P}$ & $\mathbf{R P}$ \\
\hline 5 & Eo-W & $\mathrm{RD}$ & PHS & $\mathbf{R P}$ & $\mathbf{R P}$ & $\mathbf{R P}$ \\
\hline 6 & Eo-W & $\mathrm{RD}$ & PHS & $\mathrm{RD}$ & $\mathrm{RD}$ & $\mathrm{RD}$ \\
\hline 7 & Eo-H & $\mathrm{RD}$ & - & $\mathrm{RD}$ & $\mathrm{RD}$ & Hyb (IE) \\
\hline \multicolumn{2}{|l|}{ B) } & no. & $\begin{array}{l}\text { No. SM/ } \\
\text { ind. analyzed }\end{array}$ & \multicolumn{2}{|c|}{$\% \mathrm{SM}$} & \\
\hline \multicolumn{2}{|c|}{ W (morphology) } & & $5 / 154$ & \multicolumn{2}{|l|}{3.2} & \\
\hline \multicolumn{2}{|c|}{$\mathrm{W}$ (genetics) } & & $3 / 142$ & \multicolumn{2}{|l|}{2.1} & \\
\hline \multicolumn{2}{|c|}{$\mathrm{W}^{\mathrm{a}}$ total } & & $6 / 142$ & \multicolumn{2}{|l|}{4.2} & \\
\hline \multicolumn{2}{|c|}{$\mathrm{H}^{\mathrm{b}}$ total } & & $1 / 51$ & \multicolumn{2}{|l|}{2.0} & \\
\hline \multicolumn{2}{|c|}{$\mathrm{W}+\mathrm{H}$ total } & & $7 / 193$ & \multicolumn{2}{|l|}{3.6} & \\
\hline
\end{tabular}

phology, 103 samples from Ría de Villaviciosa and 51 from Ría del Eo were identified by both fishermen and taxonomists (Table 1). According to fishermen, all samples $(100 \%)$ from both estuaries were Ruditapes decussatus. However, taxonomists acknowledged the presence of possible hybrids ( $\mathrm{n}=2$ for Ría de Villaviciosa, $1.9 \%$; $=3$ for Ría del Eo, $5.9 \%$; Table 1). Some specimens exhibited intermediate morphologies between $R$. decussatus and $R$. philippinarum (Fig. 3) as evidenced by individuals with the 2 following character combinations: (1) ovoid shaped shell, exterior of valves with reticulate pattern equally marked on whole shell surface, inside of shell with light violet tint on pallial sinus impressions and/or posterior margin of shell, pallial sinus pointing to the ventral margin of shell or straight (diagnostic of $R$. philippinarum) but lightweight, with radial and concentric reticulation equally distinct and a small and not well-defined lunule (diagnostic of $R$. decussatus); (2) shell relatively thick and heavy, reticulate pattern very marked on the whole shell surface, radial sculpture more distinct than concentric one (characters of $R$. philippinarum); lunule of intermediate size or small and the remaining features characteristic of $R$. decussatus (quadrangular shaped shell, reticulated sculpture especially marked at posterior and anterior parts of shell, inner of shell whitish without violet spots, pallial sinus usually pointed toward the top of shell or straight; Figs. 2 \& 3).

The $503 \mathrm{bp}$ mtCOI sequences obtained from PCR amplification were compared to the references that are available in GenBank for species identification. The NCBIBLAST algorithm results showed that the samples from the 3 populations were $R$. decussatus (more than $98 \%$ identical nucleotide matches and 0.0 E-values), with the exception of 2 wild Ría del Eo individuals $(4.7 \%)$ with intermediate morphology that were identified as $R$. philippinarum $199 \%$ identical nucleotide matches and 0.0 E-values; Table 1). Classification based on the nuclear markers (ITS2 and 5SrDNA) assigned almost all samples from the 3 populations as R. decussatus (482 bp of ITS2 and 593 bp of 5SrDNA; Table 1, Fig. 3). One individual from Ría de Villaviciosa morphologically identified as $R$. decussatus was found to be a post-F1 hybrid showing signals of $482 \mathrm{bp}$ and $565 \mathrm{bp}$ for the ITS2 gene and only 1 band for 5SrDNA (Fig. 3). One seed from the Ría del Eo hatchery sample exhibited amplification patterns consistent with a post-F1 hybrid with $526 \mathrm{bp}$ and $593 \mathrm{bp}$ for 5SrDNA and only 1 band for the ITS2 gene (Fig. 3). Amongst the 51 wild Ría del Eo samples, those with intermediate morphology were assigned as $R$. decussatus. The 2 remaining individuals with intermediate morphology were identified as $R$. philippinarum (565 bp of ITS2 and 526 bp of 5SrDNA; Table 1). From these results, the detected degree of possible species misidentification and introgression of NIS genes into the $R$. decussatus samples was $4.2 \%$ in wild populations, with $5.9 \%$ in Ría del Eo (donor source for supplementation strategies in the Asturian clams aquaculture and also receptor) and $3.2 \%$ in Ría de Villaviciosa (receptor); and $\sim 2 \%$ in the seeds (Eo-Hi Fig. 1, Table 1).

\section{Population diversity analysis}

The 181 mtCOI sequences of $R$. decussatus generated from the 3 samples were employed for esti- 

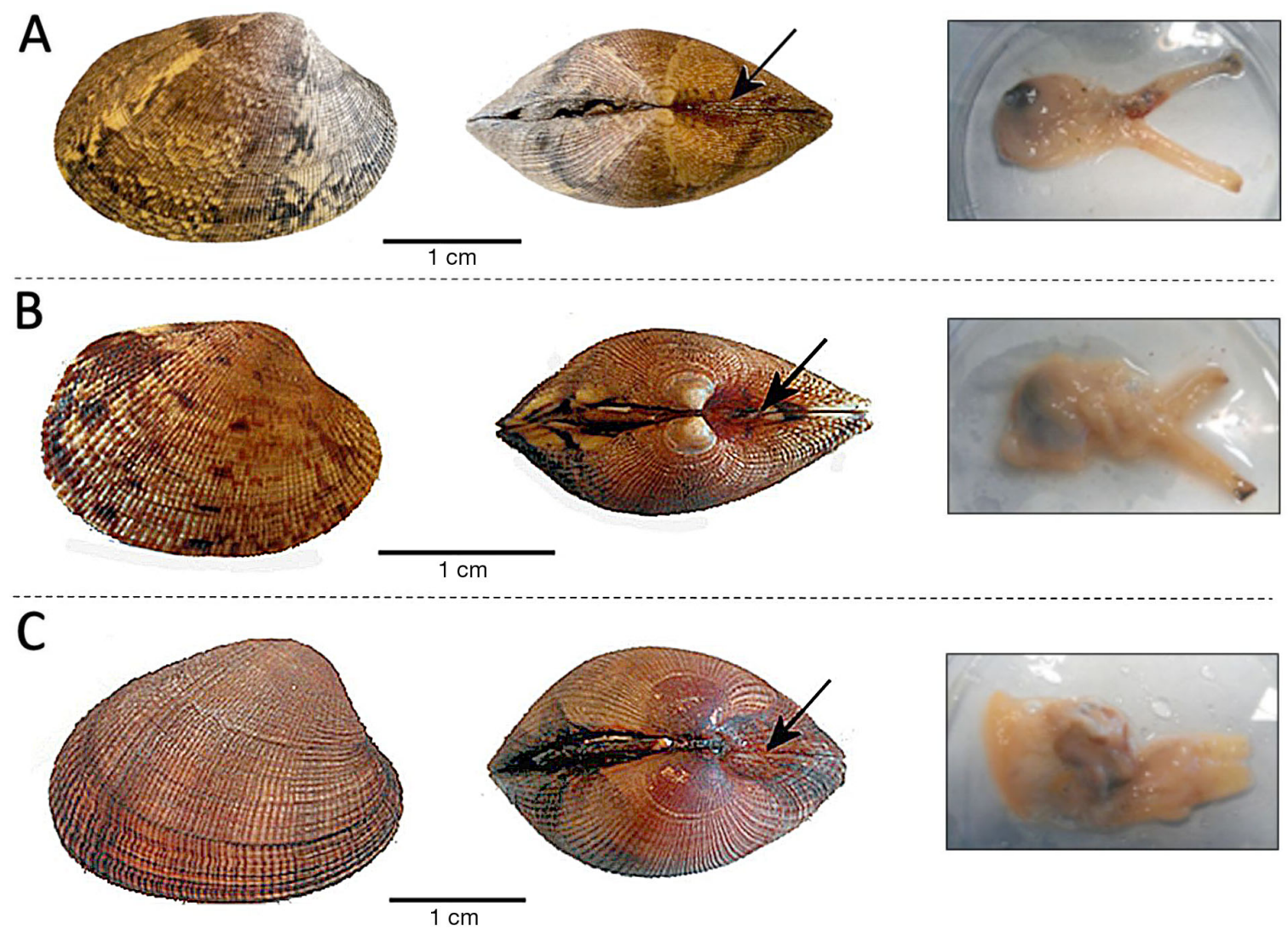

$1 \mathrm{~cm}$


Fig. 3. Morphological features of shells of Ruditapes spp.; lunules are indicated with arrows (more apparent defined heart shape at the bottom for $R$. philippinarum). Complete mollusk bodies show the siphon characteristics. Genetic assessments for nuclear markers of the sampled Ruditapes sp. in this work are also shown. (A) Post-F1 hybrid detected using nuclear genetic markers but with $R$. decussatus morphology. (B) Individual showing diagnostic characters of both $R$. philippinarum and $R$. decussatus. (C) $R$. philippinarum morphology. (D) Amplified PCR products from ITS2 nuclear genetic markers showing characteristic bands from $R$. decussatus (RD, $482 \mathrm{bp}), R$. philippinarum (RP, $565 \mathrm{bp}$ ), and hybrids. (E) Amplified PCR products from 5SrDNA nuclear genetic markers showing characteristic bands from $R$. decussatus (593 bp), R. philippinarum (526 bp), and hybrids

mating genetic population diversity after obtaining an alignment of $503 \mathrm{bp}$ (loci). The average base composition was $\mathrm{C}=16.11 \%, \mathrm{~T}=38.76 \%, \mathrm{~A}=22.46 \%$, and $\mathrm{G}=22.67 \%$. Sixteen variable nucleotide sites were found, including 9 singleton variable sites and 7 parsimony informative sites. In total, 17 haplotypes were identified and uploaded onto GenBank (accession nos. KJ560310, KJ560311, KJ560312, KJ560313,
KJ560315, KJ560317, KJ560322, KJ560328, KJ560329, KJ560331, KJ560333, KJ560334, KJ560335, KJ560339, KJ560344, KJ560356, KJ560351). Within the populations, the levels of genetic variation observed are shown in Table 2 with global haplotype diversity $h=$ $0.333 \pm 0.046$ (mean $\pm \mathrm{SD}$ ), and nucleotide diversity $\pi=0.00083$. The $h$ value ranged from $0.255 \pm 0.061$ (Ría de Villaviciosa samples) to the highest diversity 
Table 2. Genetic diversity indices of Ruditapes decussatus populations from Ría de Villaviciosa (Vill) and Ría del Eo estuaries in Asturias, northern Spain. Sample sizes (n), number of haplotypes $\left(\mathrm{n}_{\mathrm{h}}\right)$ with number of sample-specific (private) haplotypes in parentheses, number of polymorphic (segregating) sites $\left(\mathrm{n}_{\mathrm{p}}\right)$, haplotype (gene) diversity $(h)$ (mean $\pm \mathrm{SD})$, and nucleotide diversity $(\pi)$

\begin{tabular}{|lccccc|}
\hline \multirow{2}{*}{ Population } & \multicolumn{5}{c|}{ R. decussatus mtCOI, 503 loci } \\
\cline { 2 - 6 } & $\mathrm{n}$ & $\mathrm{n}_{\mathrm{h}}$ & $\mathrm{n}_{\mathrm{p}}$ & $h$ & $\pi$ \\
\hline Vill-W & 87 & $7(4)$ & 6 & $0.255 \pm 0.061$ & 0.00062 \\
Eo-W & 41 & $7(4)$ & 6 & $0.352 \pm 0.095$ & 0.00094 \\
Eo-H & 51 & $7(6)$ & 6 & $0.438 \pm 0.084$ & 0.00104 \\
Total & 179 & $17(14)$ & 16 & $0.333 \pm 0.046$ & 0.00083 \\
\hline
\end{tabular}

in the hatchery population of Ría del Eo seeds $(0.438 \pm$ 0.084 ), and $\pi$ varied from 0.00062 to 0.00104 (Table 2).

Pairwise $F_{\text {ST }}$ population comparisons showed a highly significant genetic differentiation between the hatchery and wild populations (Table 3 ). This genetic differentiation was further supported using the AMOVA. Both haplotype frequencies and sequence divergence data revealed that $96.25 \%$ of the genetic variation occurred within populations, whereas $3.75 \%$ of the genetic variation occurred among populations (Table 3 ). The total $F_{\mathrm{ST}}$ value was 0.0375 $(p<0.0001)$, suggesting significant genetic differentiation among the 3 populations.

Genetic differentiation was also noted by constructing a median joining haplotype network connecting all $R$. decussatus haplotypes found in this study from the 3 populations as well as external haplotypes (alignment of $380 \mathrm{bp)} \mathrm{(Fig.} \mathrm{4).} \mathrm{The} \mathrm{obtained} \mathrm{network}$ shows a clear star-like shape, with most haplotypes being connected by 1 mutation step (Fig. 4). Hap_6

Table 3. (A) Analysis of molecular variance (AMOVA) and (B) pairwise $F_{\text {ST }}$ values for Ruditapes decussatus from Ría de Villaviciosa (Vill) and Ría del Eo (Eo) estuaries in Asturias, northern Spain. W: wild, H: hatchery. ${ }^{*}$ Significant at $\mathrm{p}<0.05$

\begin{tabular}{|c|c|c|c|c|c|c|c|}
\hline \multicolumn{2}{|c|}{ Source of variation } & df & SS & $\begin{array}{c}\text { Variance } \\
\text { components }\end{array}$ & $\begin{array}{c}\% \text { of } \\
\text { variation }\end{array}$ & $F_{\mathrm{ST}}$ & $\mathrm{p}$ \\
\hline \multicolumn{2}{|c|}{ Among populations } & 2 & 1.300 & 0.00792 & 3.75 & 0.03750 & $<0.0001^{*}$ \\
\hline Within & opulations & 176 & 35.784 & 0.20332 & 96.25 & & \\
\hline \multicolumn{2}{|c|}{ Total } & 178 & 37.084 & 0.21124 & & & \\
\hline \multicolumn{8}{|c|}{ (B) Pairwise $F_{\mathrm{ST}}$ matrix } \\
\hline \multicolumn{3}{|c|}{ Eo-W } & \multicolumn{3}{|c|}{ Eo-H } & & \\
\hline & $F_{\mathrm{ST}}$ & $\mathrm{p}$ & & $F_{\mathrm{ST}}$ & $\mathrm{p}$ & & \\
\hline Vill-W & 0.01840 & 0.05369 & & 0.04986 & $.0001^{*}$ & & \\
\hline Eo-W & - & - & & 0.04172 & $.0001^{*}$ & & \\
\hline
\end{tabular}

(GenBank ID: KJ560310) was the most common haplotype $(65.18 \%)$ and was shared by all 3 populations under study as well as a Tunisian sample analyzed by Gharbi et al. (2010). Haplotype Hap_21 (GenBank ID: KJ560316), which accounted for $3.24 \%$ of the total population, was represented only in the wild populations of Eo and Villaviciosa, and the remaining 11 haplotypes were population-specific (private haplotypes; Fig. 4). Tests of neutrality (Tajima's $D$ and Fu's $F_{\mathrm{s}}$ ) were applied to detect demographic or selection changes, and results showed that all 3 Asturian populations were not in equilibrium but in expansion. Tajima's $D$ and Fu's $F_{\mathrm{s}}$-test results were all significantly negative at $\mathrm{p}<0.05$ (Table 4). The haplotype representation pointed to the insertion of Asturian samples in Clade A of Cordero et al. (2014) that includes Atlantic and western Mediterranean populations (Fig. 4).

\section{DISCUSSION}

Many studies reporting hybridization among animals in the wild have been related to hybridization events between native and introduced species that diverged in allopatry and lack complete reproductive isolation (Huxel 1999, Mallet 2005, Gilman \& Behm 2011). This can sometimes lead to the extirpation of native species resulting in the replacement of species pairs by what is called hybrid swarms (populations or species in which all individuals are hybrids to varying degrees; Rhymer \& Simberloff 1996, Allendorf et al. 2001, Clavero \& Garcia-Berthou 2005, Gilman \& Behm 2011). Our study demonstrates unambiguous genetic evidence of interspecific hybrids between grooved carpet shells and Manila clams in the wild populations inhabiting the estuaries of the central part of the Cantabrian coast. Moreover, occurrence of interspecific hybrids has been also detected in the hatchery stock employed for enhancement of the wild populations of Villaviciosa and Eo estuaries. Intermediate morphologies (co-existences of interspecific diagnostic characters) suggest the existence of other non-genetically detected possible cases of genetic introgression between Ruditapes spp. These findings may point to a 


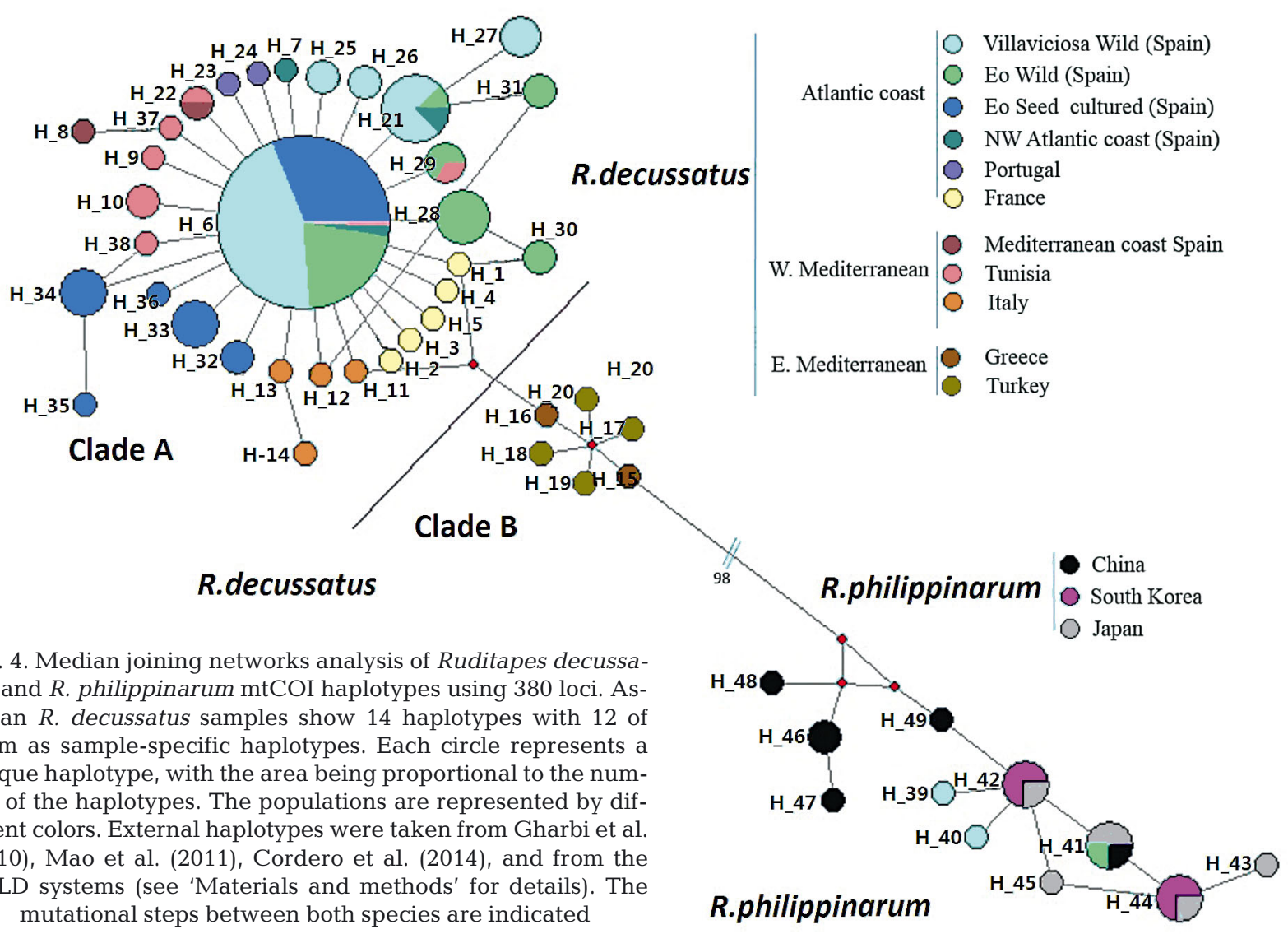

Fig. 4. Median joining networks analysis of Ruditapes decussatus and $R$. philippinarum mtCOI haplotypes using 380 loci. Asturian $R$. decussatus samples show 14 haplotypes with 12 of them as sample-specific haplotypes. Each circle represents a unique haplotype, with the area being proportional to the number of the haplotypes. The populations are represented by different colors. External haplotypes were taken from Gharbi et al. (2010), Mao et al. (2011), Cordero et al. (2014), and from the BOLD systems (see 'Materials and methods' for details). The mutational steps between both species are indicated

\section{R.philippinarum}

ber of offspring (Hedgecock \& Sly 1990, Hedgecock et al. 1992, Frost et al. 2006). Even though this issue had been pointed out for years, the problems associated with inundating a wild population with the offspring of a handful of founders have been largely ignored in current practices (Araki \& Schmid 2010, Christie et al. 2012). Supplementation campaigns thus usually result in a reduction of genetic diversity in recipient populations (Araki et al. 2009). The hatchery stock of carpet shells analyzed here exhibited higher variation at the mtCOI locus than the 2 wild populations studied, despite the reported small number of breeders. It is possible that

Table 4. Neutrality statistics for Ruditapes decussatus from Ría de Villaviciosa (Vill) and Ría del Eo estuaries in Asturias, northern Spain, using the mtCOI gene (503 bp). W: wild, H: hatchery. ${ }^{*}$ Significant at $\mathrm{p}<0.05$

\begin{tabular}{|lcrrrrr|}
\hline & \multirow{2}{*}{$\begin{array}{c}\text { Sample } \\
\text { size }\end{array}$} & \multicolumn{2}{c}{ Tajima's test } & \multicolumn{2}{c|}{ Fu's test } \\
& & & $\mathrm{p}$ & \multicolumn{2}{c|}{$F_{\mathrm{S}}$} & $\mathrm{p}$ \\
\hline Vill-W & 87 & -1.70156 & $0.01200^{*}$ & -6.09523 & $0.00100^{*}$ \\
Eo-W & 41 & -1.76319 & $0.01500^{*}$ & -5.26913 & $<0.00001^{*}$ \\
Eo-H & 51 & -1.54250 & $0.04500^{*}$ & -4.46796 & $<0.00001^{*}$ \\
Mean & 59.69 & -1.66908 & $0.02400^{*}$ & -5.27744 & $0.00033^{*}$ \\
SD & 19.75404 & 0.09298 & $0.01490^{*}$ & 0.66436 & $0.00047^{*}$ \\
\hline
\end{tabular}
past population or stock mixtures, here reflected even in the introgression from Manila clam genes, could contribute, at least partially, to increasing diversity in the hatchery stock. Nonetheless, it is well documented that great sweepstakes events occur in wild mollusks after the first life stages (Hedgecock \& Pudovkin 2011). The results of reduced genetic variation in the adults sampled from the 2 estuaries support this explanation. Al- 
though there are no previous mtDNA data from Asturian estuaries to compare levels of genetic diversity before and after the enhancement program, the sampled populations exhibited low nucleotide $(\pi)$ and haplotype diversity (h). Diversity indices, particularly nucleotide diversity, of the studied population were lower than those found for most $R$. decussatus populations along the eastern Atlantic and Mediterranean coasts (Gharbi et al. 2010, Cordero et al. 2014). Moreover, the lowest levels of genetic diversity were found in the population of Ría de Villaviciosa, which is a recurrent receptor of hatchery seeds. Overexploitation and habitat degradation might have further eroded the allelic diversity of the wild clam population. Bottlenecks can also be inferred from the star-shape haplotype network of mtCOI centered on 1 geographically widespread haplotype, a type of network that is commonly interpreted as a sign of a recent expansion following population bottlenecks (Xu et al. 2012). The observed significant negative values of Tajima's $D$ and Fu's $F_{\mathrm{s}}$ could be interpreted as signs of a selection regime associated with changing environmental variables and humaninduced disturbances, although they could also be derived from recent population expansion (for example, after a bottleneck).

For the genetic differentiation between the hatchery stock and the wild populations, the present results are concordant with the findings of Borrell et al. (2014) using microsatellites as genetic markers. Pairwise $F_{\mathrm{ST}}$ values showed significant genetic differentiation between the cultured seeds intended for supplementation and the wild populations of Ría de Villaviciosa and Ría del Eo. Erratic oscillations of haplotype frequencies are expected in such cultured stocks as a consequence of a small effective number of breeders, and could explain its different genetic pattern. On the other hand, it is possible that collection of hatchery broodstock only from Ría del Eo has contributed, at least partially, to the genetic homogenization among the wild populations. Using microsatellites, Borrell et al. (2014) did not find genetic differentiation between the 2 Asturian estuaries, and our results based on mitochondrial mtCOI fully support such a lack of divergence between spatially disjunct populations. It may indicate a common past for the species in those estuaries and/or contemporary gene flow through natural larval dispersal or anthropogenic activities such as the enhancement program. A recent study conducted in Santander Bay (Cantabrian Sea) has revealed that $R$. decussatus exhibits high self-recruitment without receiving larvae from other areas depending on the spawning season
(Bidegain et al. 2013). More than 1 reproductive migrant per generation is required in order to achieve genetic homogeneity among geographically separated populations (Borsa et al. 1994, Allendorf \& Luikart 2007). Despite this, the hypothesis of connectivity through larval dispersal should be considered cautiously here. The existence of a temperaturedependent barrier at both sides of the Peñas Cape in Asturias could influence and modulate the success of recruitment for larvae. In any case, homogenization due to stock-enhancement practices seems probable and has also been described for other aquatic species in the region, e.g. in the Atlantic salmon of Asturias, where loss of spatial population structuring was documented associated with these practices (Horreo et al. 2011).

Previous understanding of the clam species composition in Asturian estuaries was that the appearance of the exotic Manila clam in Asturias was mainly a result of pioneering culturing experiences (Carrasco \& Rodríguez 1990) and also supplementation campaigns (CEP pers. comm.). In the 1980s, the seeds used for enhancements came from private companies, and government stakeholders believe that this was the source for this human-mediated biological invasion. Hurtado et al. (2011) demonstrated that those 2 species ( $R$. decussatus and $R$. philippinarum) can hybridize, and they found genetic and cytological evidence of the occurrence of hybridization between female $R$. decussatus and male $R$. philippinarum using $16 \mathrm{~S}$ mitochondrial rDNA, ITS2, and 5SrDNA genes. Kitada et al. (2013) also demonstrated hybrids of $R$. philippinarum and other Ruditapes forms. It is believed that hybrid swarms are a virtually intractable problem and that rapid detection of hybridization and response is critical. To date, no one has assessed whether, and to what extent, hybridization occurs in Asturian wild environments. Perhaps one the most important findings of this study was introgression of exotic species into native gene pools. We found $3.2 \%$ and $2.1 \%$ of possible species misidentification and introgression events using taxonomic and genetic analysis, respectively. By populations, our study revealed $5.9 \%$ for the source and receptor populations of the supplementation campaigns (Ría del Eo) and about a half of this, 3.2\%, for the receptor population Ría de Villaviciosa. These values are in the same ranges of what was found for another wild population in Galicia (4\%) by Hurtado et al. (2011). In that study, more individuals were analyzed, but a taxonomic approach was not used. Of note is that the regions of Asturias and Galicia have shared seeds for supplementation campaigns in the 
past, when seeds were scarce, according to local producers. This adds another possible source for NIS genomes introgressed in native clams in Asturias (red arrows in Fig. 1).

Our study demonstrates that individuals can share morphological characters typically assigned to $R$. decussatus with diagnostic characters from specimens of $R$. philippinarum (and vice versa). Moreover, introgression events revealed by nuclear genetic markers were also detected in cases where there was no cooccurrence of interspecific diagnostic morphological characters. In many cases, morphological intermediacy and molecular confirmation of hybridization go hand in hand (Allendorf et al. 2001). However, in this study, the introgressed genetic marker (ITS2, $565 \mathrm{bp}$ ) was found in individuals of apparent morphologically pure phenotypes, whereas individuals with intermediate (ambiguous) morphology were genetically assigned as pure species. The recognized hybrids exhibited double fragment base pairs for only 1 of 2 nuclear markers (ITS2 and 5SrDNA) employed in the identification of the 2 taxa. This indicates that these individuals were either post first generation (F1) hybrids or backcrosses with 1 of the parental taxa. In the case of post F1 hybrids or backcrosses, most genes come from 1 of the parental taxa, the recurrent one (Leary et al. 1995, Allendorf et al. 2001). Thus, morphological identification of the studied parental species from their hybrids becomes difficult because they are more and more similar to the recurrent parent species in successive post F1 generations. Despite this, since after several backcrosses genetic evidence of introgression can also be lost, taxonomic approaches are then also necessary, and indeed, they were useful in this work. For captive breeding programs, individuals showing some of the diagnostic taxonomic characters from $R$. philippinarum must be discarded.

The degree of hybridization detected in Galicia by Hurtado et al. (2011) and in our study in Asturias was low. However, only a few diagnostic loci were used. Managers, stakeholders, fishermen, and scientists must now work together. The peak in gamete emission periods for $R$. decussatus in the wild has been reported from April onwards (Delgado \& Pérez-Camacho 2007) and from April to September for $R$. philippinarum (Rodríguez- Moscoso et al. 1992), and the role of factors such as temperature and salinity under lab conditions for spawning has also been assessed (Delgado \& Pérez-Camacho 2007, Joaquim et al. 2008, Matias et al. 2009). Results of those studies showed interspecific differences and indicated that, perhaps, simultaneous spawning under natural conditions for both species does not occur very frequently (Carrilho 2012). At the same time, no information is available about the fitness of the hybrid individuals in nature for Ruditapes sp. In absence of more data, it seems clear that artificially induced spawning using hybrid individuals in captive programs could be currently contributing to widespread hybridization in wild environments. The presence of post F1 hybrids in the seeds from the enhancement hatchery facility confirms the genetic introgression from $R$. philippinarum to $R$. decussatus, so this practice is likely threatening the genetic integrity of the native clam. At this point, we recommend (1) immediately prohibiting the release of alien $R$. philippinarum into natural waters, (2) developing hybridization diagnostic tests using more diagnostic characters combining taxonomic and genetic approaches, (3) studying supplemented and non-supplemented $R$. decussatus populations from Cantabrian coasts for identification of the pure populations of the taxon still remaining in the region and also defining the conservation value of current populations, and finally (4) identifying non-hybridized individuals to be used in captive breeding.

In conclusion, this study showed the existence of gene introgression from the Manila clam into the native grooved carpet shell in Asturias, northern Spain. Our results demonstrate that morphological and genetic identification of $R$. decussatus should be combined when planning aquaculture strategies. Occurrence of post F1 hybrids in adults, and moreover in the seedlings, confirmed the enhancement stock as a possible source of genetic introgression from the exotic $R$. philippinarum into the $R$. decussatus native gene pool. On the other hand, genetic differentiation between the seeds used for the supplementation and the wild recipient populations has been confirmed, as well as the possible role of these seeds as active agents in shaping the genetic patterns found in the wild clam's population in Asturian estuaries.

Acknowledgements. We are grateful to Jacobo López, Carmen Rodríguez, and José Francisco Carrasco (IEO, Castropol-Gijón) for providing us with background information about Asturian aquaculture and operational procedures of the Castropol hatchery facilities (Ría del Eo). This work was funded by University of Oviedo, Asturian and Spanish governments through the projects UNOV-13-EMERG-05, SV-PA-13-ECOEMP-41 and the National Project MINECO CGL2013-42415-R. B.T.H. was supported by the EMBC Master Programme 2012-2014. This paper is a contribution from the Marine Observatory of Asturias (OMA) and the research group GRUPIN14-093. 


\section{LITERATURE CITED}

Allendorf FW, Luikart G (2007) Conservation and the genetics of populations. Blackwell Publishing, Malden, MA

- Allendorf FW, Leary RF, Spruell P, Wenburg JK (2001) The problems with hybrids: setting conservation guidelines. Trends Ecol Evol 16:613-622

> Araki H, Schmid C (2010) Is hatchery stocking a help or harm? Evidence, limitations and future directions in ecological and genetic surveys. Aquaculture 308(Suppl 1): $\mathrm{S} 2-\mathrm{S} 11$

Araki H, Cooper B, Blouin MS (2009) Carry-over effect of captive breeding reduces reproductive fitness of wildborn descendants in the wild. Biol Lett 5:621-624

> Arias A, Anadón N (2012) First record of Mercenaria mercenaria (Bivalvia: Veneridae) and Ensis directus (Bivalvia: Pharidae) on Bay of Biscay, Iberian peninsula. J Shellfish Res 31:57-60

Bandelt HJ, Forster P, Röhl A (1999) Median-joining networks for inferring intraspecific phylogenies. Mol Biol Evol 16:37-48

Bert TM, Crawford CR, Tringali MD, Seyoum S, Galvin JL, Higham M, Lund C (2007) Genetic management of hatchery-based stock enhancement. In: Bert TM (ed) Ecological and genetic implications of aquaculture activities. Springer, Dordrecht, p 123-174

Bidegain G, Juanes JA (2013) Does expansion of Manila clam Ruditapes philippinarum cause competitive displacement of the European native clam Ruditapes decussatus? J Exp Mar Biol Ecol 445:44-52

Bidegain G, Barcena FJ, Garcia A, Juanes AJ (2013) LARVAHS: predicting clam larval dispersal and recruitment using habitat suitability-based particle tracking model. Ecol Model 268:78-92

Blankenship HL, Leber KM (1995) A responsible approach to marine stock enhancement. Am Fish Soc Symp 15: 167-175

- Borrell YJ, Arias-Pérez A, Freire R, Valdés A and others (2014) Microsatellites and multiplex PCRs for assessing aquaculture practices of the grooved carpet shell Ruditapes decussatus in Spain. Aquaculture 426-427:49-59

Borsa P, Jarne P, Belkhir K, Bonhomme F (1994) Genetic structure of the palourde Ruditapes decussatus in the Mediterranean. In: Beaumont AR (ed) Genetics and evolution of aquatic organisms. Chapman \& Hall, London, p 102-113

Carrasco JF, Rodríguez C (1990) Cultivo de la almeja Ruditapes philippinarum. Resultados de crecimiento en función del tipo de sustrato y de la altura de marea. In: Landín A, Cerviño A (eds) Actas del III Congreso Nacional de Acuicultura, Santiago de Compostela, 24-27 Sept 1990. Consellería de Pesca, Marisqueo e Acuicultura, Santiago de Compostela, p 575-580

Carrilho J (2012) Caracterização e mapeamento de marcadores moleculares em espécies da família Veneridae de interesse comercial em Portugal e Espanha. Estudo da hibridação entre Ruditapes decussatus e Ruditapes philippinarum. PhD thesis, Universidade do Porto

Chiesa S, Lucentini L, Freitas R, Nonnis Marzano F and others (2014) Genetic diversity of introduced Manila clam Ruditapes philippinarum populations inferred by 16SrDNA. Biochem Syst Ecol 57:52-59

Christie MR, Marine ML, French RA, Waples RS, Blouin MS (2012) Effective size of a wild salmonid population is greatly reduced by hatchery supplementation. Heredity
109:254-260

> Cigarría J, Rodriguez C, Fernández JM (1997) Impact of Perkinsus sp. on Manila clam Ruditapes philippinarum beds. Dis Aquat Org 29:117-120

Clavero M, Garcia-Berthou E (2005) Invasive species are a leading cause of animal extinctions. Trends Ecol Evol 20: 110

Cordero D, Peña JB, Saavedra C (2014) Phylogenetic analysis of introns and mitochondrial DNA in the clam Ruditapes decussatus uncovers the effects of Pleistocene glaciations and indigenous barriers to gene flow. Mol Phylogenet Evol 71:274-287

Crego-Prieto V, Ardura A, Juanes F, Roca A, Taylor JS, Garcia-Vazquez E (2015) Aquaculture and the spread of introduced mussel genes in British Columbia. Biol Invasions (in press) doi:10.1007/s10530-015-0853-z

> Delgado M, Pérez-Camacho A (2007) Comparative study of gonadal development of Ruditapes philippinarum (Adams and Reeve) and Ruditapes decussatus (L.) (Mollusca: Bivalvia): influence of temperature. Sci Mar 71:471-484

Dickson RR, Hughes DG (1981) Satellite evidence of mesoscale eddy activity over the Biscay abyssal plain. Oceanol Acta 4:43-46

Excoffier L, Laval G, Schneider S (2005) Arlequin ver. 3.0: an integrated software package for population genetics data analysis. Evol Bioinform Online 1:47-50

Frost LA, Evans BS, Jerry DR (2006) Loss of genetic diversity due to hatchery culture practices in barramundi (Lates calcarifer). Aquaculture 261:1056-1064

> Fu YX (1997) Statistical tests of neutrality of mutations against population growth, hitch-hiking, and background selection. Genetics 147:915-925

> Gaffney PM (2006) The role of genetics in shellfish restoration. Aquat Living Resour 19:277-282

García-Pérez JA, Carrasco JF, Rodriguez C, Arronte JC (2007) Producción de semilla de almeja fina (Ruditapes decussatus L. 1758) en criadero para repoblación en el Principado de Asturias. In: Cerviño A, Guerra A, Pérez C (eds) Actas del XI Congreso Nacional de Acuicultura, Vigo, 25-28 Sept 2007. Centro de Investigacións Mariñas de Coron and Consellería de Pesca e Asuntos Marítimos, Santiago de Compostela, p 399-402

> Geller J, Meyer C, Parker M, Hawk H (2013) Redesign of PCR primers for mitochondrial cytochrome c oxidase subunit I for marine invertebrates and application in alltaxa biotic surveys. Mol Ecol Resour 13:851-861

Gharbi A, Chatti N, Said K, VanWormhoudt A (2010) Genetic variation and population structure of the carpet shell clam Ruditapes decussatus along the Tunisian coast inferred from mtDNA and ITS1 sequence analysis. Biologia 65:688-696

Gilman RT, Behm JE (2011) Hybridization, species collapse, and species reemergence after disturbance to premating mechanisms of reproductive isolation. Evolution 65: 2592-2605

Gofás S, Moreno D, Salas C (2011) Moluscos marinos de Andalucía: II. Clase Gastropoda (Heterobranchia), clase Bivalvia, clase Scaphopoda, clase Cephalopoda, glosario e índices. Servicio de Publicaciones e Intercambio Científico, Universidad de Málaga, Málaga

Hall TA (1999) BioEdit: a user-friendly biological sequence alignment editor and analysis program for Windows 95/98/NT. Nucleic Acids Symp Ser 41:95-98

Hebert PDN, Cywinska A, Ball SL, DeWaard JR (2003) Biological identifications through DNA barcodes. Proc R Soc 
Lond B Biol Sci 270:313-321

Hedgecock D, Pudovkin AI (2011) Sweepstakes reproductive success in highly fecund marine fish and shellfish: a review and commentary. Bull Mar Sci 87:971-1002

> Hedgecock D, Sly F (1990) Genetic drift and effective population sizes of hatchery-propagated stocks of the Pacific oyster, Crassostrea gigas. Aquaculture 88:21-38

> Hedgecock D, Chow V, Waples RS (1992) Effective population number of shellfish broodstocks estimated from temporal variance in allelic frequencies. Aquaculture 108: 215-232

> Horreo JL, Machado-Schiaffino G, Ayllon F, Griffiths AM, Bright D, Stevens JR, Garcia-Vazquez E (2011) Impact of climate change and human-mediated introgression on South European Atlantic salmon populations. Glob Change Biol 17:1778-1787

> Hurtado NS, Perez-García C, Moran P, Pasantes JJ (2011) Genetic and cytological evidence of hybridization between native Ruditapes decussatus and introduced Ruditapes philippinarum (Mollusca, Bivalvia, Veneridae) in NW Spain. Aquaculture 311:123-128

> Huvet A, Fabioux C, McCombie $\mathrm{H}$, Lapègue S, Boudry $\mathrm{P}$ (2004) Natural hybridization between genetically differentiated populations of Crassostrea gigas and $C$. angulata highlighted by sequence variation in flanking regions of a microsatellite locus. Mar Ecol Prog Ser 272: 141-152

> Huxel GR (1999) Rapid displacement of native species by invasive species: effects of hybridization. Biol Conserv 89:143-152

Jensen AC, Humphreys J, Caldow RWG, Grisley C, Dyrynda PEJ (2004) Naturalization of the Manila clam (Tapes philippinarum), an alien species, and establishment of a clam fishery within Poole Harbour, Dorset. J Mar Biol Assoc UK 84:1069-1073

Joaquim S, Matias D, Moreno O (2008) Cultivo de bivalvos en criadero / Cultivo de bivalves em maternidade. Junta de Andalucía, Instituto de Investigación y Formación Agraria y Pesquera, Conserjería de Agricultura y Pesca, Sevilla

> Juanes JA, Bidegain G, Echavarri-Erasun B, Puente A and others (2012) Differential distribution pattern of native Ruditapes decussatus and introduced Ruditapes philippinarum clam populations in the Bay of Santander (Gulf of Biscay): considerations for fisheries management. Ocean Coast Manag 69:316-326

Kitada S, Fujikake C, Asakura Y, Yuki H and others (2013) Molecular and morphological evidence of hybridization between native Ruditapes philippinarum and the introduced Ruditapes form in Japan. Conserv Genet 14: $717-733$

Laruelle F, Guillou J, Paulet YM (1994) Reproductive pattern of the clams, Ruditapes decussatus and $R$. philippinarum on intertidal flats in Brittany. J Mar Biol Assoc UK 74: 351-366

Leary RF, Allendorf FW, Sage GK (1995) Hybridization and introgression between introduced and native fish. Am Fish Soc Symp 15:91-101

Librado P, Rozas J (2009) DnaSP v5: a software for comprehensive analysis of DNA polymorphism data. Bioinformatics 25:1451-1452

López J, Carrasco JF, Rodríguez C (2009) Desarrollo larvario de Ruditapes decussatus (Linnaeus, 1758) en función de la escala de cultivo del fitoplancton suministrado. In: Rey-Méndez M, Fernández Casal J, Lodeiros C, Guerra
A (eds) XII Foro dos Recursos Mariños e da Acuicultura das Rías Gallegas, O Grove, 9-10 Oct 2009, Santiago de Compostela 12:327-332

López J, Rodríguez C, Carrasco JF (2010) Cultivo y repoblación de almeja fina (Ruditapes decussatus) en el Principado de Asturias: 2009-2010. In: Rey-Méndez M, Lodeiros C, Fernández Casal J, Guerra A (eds) XIII Foro dos Recursos Mariños e da Acuicultura das Rías Gallegas, O Grove, 7-8 Oct 2010, Santiago de Compostela 13: $259-265$

López J, Carrasco JF, Rodríguez C (2011) Producción de semilla de almeja fina (Ruditapes decussatus) en el Principado de Asturias dentro del Proyecto 'Optimización del cultivo intensivo de la almeja'. In: Rey-Méndez M, Fernández Casal J, Lodeiros C, Guerra A (eds) XIV Foro dos Recursos Mariños e da Acuicultura das Rías Gallegas, O Grove, 6-7 Oct 2011, Santiago de Compostela 14: 341-345

López J, Carrasco JF, Rodríguez C, De la Uz S (2013) Repoblaciones de almeja fina (Ruditapes decussatus) en el Principado de Asturias 2009-2012. In: XIV Congreso Nacional de Acuicultura, Gijón, 23-25 Sept 2013, p 264-265

Lorenzen K, Steneck RS, Warner RR, Parma AM, Coleman FC, Leber KM (2010) The spatial dimensions of fisheries: putting it all in place. Bull Mar Sci 86:169-177

> Mallet J (2005) Hybridization as an invasion of the genome. Trends Ecol Evol 20:229-237

Mao YL, Gao TX, Yanagimoto T, Xiao YS (2011) Molecular phylogeography of Ruditapes philippinarum in the Northwestern Pacific Ocean based on COI gene. J Exp Mar Biol Ecol 407:171-181

Masuda R, Tsukamoto K (1998) Stock enhancement in Japan: review and prospective. Bull Mar Sci 62:337-358

> Matias D, Joaquim S, Leitão A, Massapina C (2009) Effect of geographic origin, temperature and timing of broodstock collection on conditioning, spawning success and larval viability of Ruditapes decussatus (Linné, 1758). Aquacult Int 17:257-271

> Molnar JL, Gamboa RL, Revenga C, Spalding MD (2008) Assessing the global threat of invasive species to marine biodiversity. Front Ecol Environ 6:485-492

> Molony BW, Lenanton R, Jackso G, Norriss J (2003) Stock enhancement as a fisheries management tool. Rev Fish Biol Fish 13:409-432

> Moreira R, Balseiro P, Romero A, Dios S, Posada D, Novoa B, Figueras A (2012) Gene expression analysis of clams Ruditapes philippinarum and Ruditapes decussatus following bacterial infection yields molecular insights into pathogen resistance and immunity. Dev Comp Immunol 36:140-149

Muñoz-Colmenero M, Turrero P, Horreo JL, Garcia-Vazquez E (2012) Evolution of limpet assemblages driven by environmental changes and harvesting in North Iberia. Mar Ecol Prog Ser 466:121-131

Olenin S, Minchin D, Daunys D, Zaiko A (2010) Pathways of aquatic invasions in Europe. In: Settele J, Penev LD, Georgiev TA, Grabaum R and others (eds) Atlas of biodiversity risk. Pensoft Publishers, Sofia, p 138-139

Plazzi F, Passamonti M (2010) Towards a molecular phylogeny of mollusks: bivalves' early evolution as revealed by mitochondrial genes. Mol Phylogenet Evol 57:641-657

Poppe GT, Goto Y (2000) European seashells, Vol II. Scaphopoda, Bivalvia, Cephalopoda. ConchBooks, Hackenheim 
Quéro JC, Vayne JJ (1998) Les fruits de la mer et les plantes marines des pêches françaises. Delachaux et Niestlé / Ifremer

Rawson PD, Agrawal V, Hilbish TJ (1999) Hybridization between the blue mussels Mytilus galloprovincialis and M. trossulus along the Pacific coast of North America: evidence for limited introgression. Mar Biol 134:201-211

Rhymer JM, Simberloff D (1996) Extinction by hybridization and introgression. Annu Rev Ecol Syst 27:83-109

Rios A, Fraga F, Figueras FG, Prego R, Perez FF (1987) Campañas oceanográficas Asturias I, II, III y IV. Datos Inf Inst Invest Mar 22:1-140

Rodríguez-Moscoso E, Pazo JP, García A, Fernández-Cortés F (1992) Reproductive cycle of Manila clam, Ruditapes philippinarum (Adam \& Reeve 1850), in Ria of Vigo (NW Spain). Sci Mar 56:61-67

Roodt-Wilding R (2007) Abalone ranching: a review on genetic considerations. Aquacult Res 38:1229-1241

Ruiz GM, Carlton JT, Grosholz ED, Hines AH (1997) Global

Editorial responsibility: Kevin Glover,

Bergen, Norway invasions of marine and estuarine habitats by nonindigenous species: mechanisms, extent, and consequences. Am Zool 37:621-632

Tajima F (1989) Statistical method for testing the neutral mutation hypothesis by DNA polymorphism. Genetics 123:585-595

Tave D (1999) Inbreeding and brood stock management. FAO Fish Tech Pap 392. FAO, Rome

Tebble N (1966) British bivalve seashells. British Museum (Natural History), London

Utter F (1998) Genetic problems of hatchery-reared progeny released into the wild, and how to deal with them. Bull Mar Sci 62:623-640

Utter F, Epifanio J (2002) Marine aquaculture: genetic potentialities and pitfalls. Rev Fish Biol Fish 12:59-77

Xu D, Lou B, Shi H, Geng Z, Li S, Zhang Y (2012) Genetic diversity and population structure of Nibea albiflora in the China Sea revealed by mitochondrial mtCOI sequences. Biochem Syst Ecol 45:158-165

Submitted: July 16, 2014; Accepted: February 26, 2015

Proofs received from author(s): April 8, 2015 